\title{
KEEFEKTIFAN PENGEMBANGAN PERANGKAT PEMBELAJARAN MODEL PROBLEM SOLVING UNTUK MELATIHKAN KETERAMPILAN BERPIKIR KREATIF SISWA
}

\author{
Anik Indrayani ${ }^{1)}$, Endang Susantini ${ }^{2)}$, Wahono Widodo ${ }^{3)}$ \\ ${ }^{1)}$ Mahasiswa Program Studi Pendidikan Sains, Program Pascasarjana Universitas Negeri Surabaya \\ ${ }^{2), 3)}$ Dosen Pascasarjana Prodi Pendidikan Sains Univesrtitas Negeri Surabaya \\ E-mail: anik.indra@gmail.com
}

\begin{abstract}
This research was aimed to describe the effectiveness of learning materials taht developed using problem solving model to facilitate junior high school students' creative thinking skills on global warming. This research was done because the problem solving model's learning materials to facilitate students' creative thinking skill was less available. Learning in schools was tend to emphasize the aspects of knowledge only, whereas creative thinking skill was an important skill possessed in the $21^{\text {st }}$ century. Applying creative thinking skill in problem solving would generate a lot of ideas that were useful in finding solution. The learning materials were developed using 3D model and one group pretest-posttest design was used as the trial design. The subject in this study was learning materials that was implemented on $7^{\text {th }}$ grade students of SMP Negeri 1 Kediri. The results showed that the students' creative thinking skills both in general and each indicator increased. Based on the results and discussion of the study, it can be concluded that the learning materials using problem solving method were effective to facilitate junior high school students' creative thinking skills on global warming.
\end{abstract}

Keywords: Problem Solving Method, Creative Thinking Skills, Global Warming

Abstrak: Penelitian ini bertujuan untuk mendeskripsikan keefektifan perangkat pembelajaran yang dikembangkan dengan model problem solving untuk melatihkan keterampilan berpikir kreatif siswa SMP pada materi pemanasan global. Hal ini dilakukan karena perangkat pembelajaran dengan model problem solving untuk melatihkan keterampilan berpikir kreatif kurang tersedia. Pembelajaran di sekolah cenderung menekankan pada aspek pengetahuan saja, padahal keterampilan berpikir kreatif merupakan skill yang penting dimiliki pada abad 21. Penerapan berpikir kreatif dalam problem solving akan menghasilkan banyak ide yang berguna dalam menemukan penyelesaian masalah. Perangkat pembelajaran dikembangkan menggunakan model 3D dengan rancangan ujicoba penelitian one group pretest-posttest design. Subyek dalam penelitian ini adalah perangkat pembelajaran model problem solving yang diujicobakan pada 32 siswa SMP Negeri 1 Kediri kelas VII. Hasil penelitian menunjukkan bahwa keterampilan berpikir kreatif siswa baik secara umum maupun tiap indikator meningkat. Berdasarkan hasil penelitian dan diskusi hasil penelitian dapat disimpulkan bahwa perangkat pembelajaran model problem solving efektif untuk melatihkan keterampilan berpikir kreatif siswa SMP pada materi pemanasan global.

Kata kunci: Model Problem Solving, Keterampilan Berpikir Kreatif, Pemanasan Global

\section{PENDAHULUAN}

Manusia selalu berhadapan dengan dunia sains mulai dari hal sederhana sampai kompleks. Pengamatan benda bergerak, beraneka ragam tumbuhan dan hewan, serta berbagai fenomena alam sangat terkait dengan Ilmu Pengetahuan Alam (IPA) dan membutuhkan pengamatan atau penelusuran secara ilmiah. Sesuai dengan hakekat Kurikulum 2013, pembelajaran IPA meliputi pengetahuan, keterampilan, dan sikap serta kemampuan berpikir melalui interaksi langsung dengan sumber belajar. Ilmu Pengetahuan Alam tidak hanya mengajarkan sekumpulan fakta, konsep dan teori tentang alam semesta, tetapi juga mengajak siswa untuk melakukan observasi, eksperimen, klasifikasi atau pengukuran terhadap suatu kejadian atau fenomena alam sehingga diperoleh data yang akurat. Pengetahuan dan kreativitas diperlukan untuk mengolah dan menganalisis data menjadi suatu hasil ilmiah yang berguna bagi kemajuan IPA.

Nash dalam Samatowa (2006) menyatakan bahwa cara IPA mengamati dunia adalah bersifat analisis, lengkap, cermat serta menghubungkan antara satu fenomena dengan fenomena lain, sehingga keseluruhannya membentuk suatu prespektif yang baru tentang objek yang diamatinya. Jadi penekanan pembelajaran IPA adalah pengembangan kreativitas 
siswa dalam mengelola pemikirannya dalam menghubungkan satu fenomena dengan fenomena lain yang ada di lingkungannya, sehingga memperoleh suatu gagasan (ide), pemahaman, serta pola baru dalam berpikir memahami suatu objek yang diamati.

Ilmu Pengetahuan Alam diperlukan dalam kehidupan sehari-hari untuk memenuhi kebutuhan manusia melalui pemecahan masalah-masalah yang dapat diidentifikasikan. Sains/IPA adalah aktivitas pemecahan masalah oleh manusia yang termotivasi oleh keingintahuan akan alam sekitar dan keinginan untuk memahami, menguasai, dan mengelolanya demi memenuhi kebutuhan. Hal ini sesuai dengan Permendikbud No. 58 tahun 2014 yang menyatakan bahwa tujuan pembelajaran IPA yaitu mengembangkan kemampuan bernalar dalam berpikir analisis induktif dan deduktif dengan menggunakan konsep dan prinsip IPA untuk menjelaskan berbagai peristiwa alam dan menyelesaikan masalah baik secara kualitatif maupun kuantitatif. IPA hakikatnya tidak hanya mengajarkan pengetahuan (kognitif) saja, tetapi juga melatihkan sikap dan keterampilan yang dibutuhkan siswa dalam mengatasi berbagai masalah yang ada dan belajar bagaimana berinteraksi dengan orang lain.

Salah satu jenis keterampilan yang dibutuhkan siswa adalah keterampilan berpikir. Menurut Trilling \& Fadel (2009), keterampilan berpikir merupakan kunci pembuka pembelajaran sepanjang hayat dan kerja kreatif. Berpikir dan pengetahuan merupakan alat bantu/pendukung untuk belajar, bekerja dan menjadi kreatif. Namun sayangnya keterampilan berpikir siswa Indonesia masih rendah. Analisis hasil studi The Trends in International Mathematics and Science Study (TIMSS) dan The Programme for International Student Assessment (PISA) menunjukkan bahwa siswa Indonesia berada pada peringkat bawah dan kurang menguasai kemampuan memahami informasi yang kompleks, pemecahan masalah (teori, analisis, pemakaian alat, prosedur) dan investigasi. Posisi Indonesia dalam TIMSS sampai tahun 2011 masih berada pada low international benchmark (nilai <500) pada siswa tingkat 8 . Nilai ini menunjukkan bahwa siswa Indonesia hanya mampu mengenali sejumlah fakta dasar tapi belum mampu mengkomunikasikan dan mengaitkan berbagai topik sains, apalagi menerapkan konsep-konsep yang kompleks dan abstrak (Odja dkk., 2014). Berdasarkan fakta tersebut, keterampilan berpikir perlu dilatihkan.

Salah satu keterampilan berpikir yang penting adalah keterampilan berpikir kreatif. Keterampilan berpikir kreatif perlu dilatihkan karena berdasarkan Global Creativity Index tahun 2010 yang dipublikasikan oleh Martin Prosperity Institute, Indonesia menempati peringkat 81 dari 82 negara (Florida et al., 2011). Hal ini menunjukkan bahwa tingkat kreativitas Indonesia masih sangat rendah, padahal abad 21 menuntut lulusan memiliki keterampilan tingkat tinggi seperti inovasi dan kreativitas (Trilling \& Fadel, 2009). Hal ini sejalan dengan Piirto (2011) yang menyatakan bahwa keterampilan berpikir kreatif merupakan skill yang penting dimiliki pada abad 21. Arus globalisasi, berbagai isu yang terkait dengan masalah lingkungan hidup, kemajuan teknologi dan informasi, kebangkitan industri kreatif dan budaya, dan perkembangan pendidikan di tingkat internasional akan mampu dihadapi dengan adanya keterampilan berpikir kreatif yang dimiliki.

Berpikir kreatif sangat penting bagi keberhasilan dalam belajar dan keberhasilan dalam hidup karena melibatkan berbagai keterampilan yang dapat digunakan pada lintas kurikulum dan dapat diintegrasikan di semua bidang kehidupan. Berpikir kreatif diperlukan untuk menciptakan inovasi-inovasi baru. Berbagai keterampilan yang diperlukan dalam angkatan kerja memerlukan kemampuan untuk berpikir kreatif dan kemampuan pemecahan masalah secara kreatif. Indonesia melalui Kurikulum 2013 berusaha menghadapi tuntutan abad 21 melalui pendidikan secara komprehensif (aspek sikap, keterampilan, dan pengetahuan). Dari aspek keterampilan, lulusan tingkat SMP/sederajat diharapkan mempunyai kemampuan pikir dan tindak yang efektif dan kreatif dalam ranah abstrak dan konkret sesuai dengan yang dipelajari di sekolah dan sumber lain sejenis (Permendikbud Nomor 54 Tahun 2013).

Keterampilan berpikir kreatif yaitu suatu proses berpikir yang menghasilkan bermacam-macam kemungkinan jawaban (berpikir divergen) yang didasarkan pada intuisi tetapi masih rasional. Berpikir kreatif merupakan kombinasi antara berpikir logis dan berpikir divergen. Penerapan berpikir kreatif dalam pemecahan masalah akan menghasilkan banyak ide-ide yang berguna dalam menemukan penyelesaian masalah. Munandar (2012) menjelaskan bahwa perkembangan optimal dari kemampuan berpikir kreatif berhubungan erat dengan proses pembelajaran. Berpikir kreatif akan muncul dalam suasana pembelajaran yang menyenangkan, memotivasi siswa untuk berpartisipasi aktif, memberikan ruang kepada siswa untuk berpikir dan berani mengemukakan pendapat, atau ketika siswa diberi kesempatan untuk bekerja sesuai dengan minatnya.

Berpikir kreatif siswa akan muncul salah satunya adalah dengan penerapan model pemecahan masalah (problem solving) pada pembelajaran. Hal ini diantaranya sejalan dengan teori psikoanalisis yang melihat kreativitas sebagai hasil mengatasi suatu masalah yang biasanya dimulai pada masa anak-anak (Munandar, 2012). Secara umum, model pembelajaran 
problem solving adalah suatu model penyajian bahan pembelajaran dengan menyajikan suatu masalah yang harus dipecahkan atau diselesaikan oleh siswa untuk mencapai tujuan pembelajaran tertentu. Model pembelajaran problem solving menuntut siswa menyelesaikan suatu masalah (baik secara individu maupun kelompok) dengan berbagai cara dan teknik. Dalam pembelajaran problem solving, siswa diarahkan untuk melakukan penyelidikan autentik untuk mencari penyelesaian terhadap masalah yang diberikan dengan cara mengidentifikasi masalah dan peluang, mendefinisikan tujuan, mengeksplorasi strategi yang mungkin, mengantisipasi hasil dan tindakan, dan melihat kembali dan pelajari (Bransford dan Stein dalam Slavin, 2011).

Monahan (2002) menyatakan bahwa pemecahan masalah (problem solving) merupakan faktor penting dalam proses berpikir kreatif. VanGundy (2005) juga menyatakan bahwa problem solvers akan berusaha untuk menghasilkan berbagai alternatif solusi yang berbeda. Solusi yang dihasilkan dapat berupa ide dan ide bersifat divergen. Kemampuan berpikir divergen merupakan indikator dari kreativitas (Munandar, 2012). Dengan demikian pembelajaran problem solving antara lain dapat menjadikan siswa aktif dan kreatif dalam menyelesaikan suatu masalah.

Masalah yang dipilih dalam pembelajaran problem solving dapat berasal dari guru maupun dari fakta yang ada di lingkungan sekitar (autentik). Salah satu fakta lingkungan yang mendunia dan dipelajari oleh siswa sekolah menengah pertama (SMP) adalah pemanasan global. Materi pemanasan global adalah materi yang menarik bagi siswa karena bersifat konteksual atau terkait dengan kehidupan sehari-hari dan menjadi perbincangan hangat akhir-akhir ini.

Materi pemanasan global pada Kurikulum 2013 tercakup pada kompetensi dasar (KD) 1.1, 2.1, 3.10, dan 4.13. Dari aspek pengetahuan (KD 3.10), siswa diharapkan dapat mendeskripsikan tentang penyebab terjadinya pemanasan global dan dampaknya bagi ekosistem. Dari aspek keterampilan (KD 4.13), berpikir kreatif siswa diperlukan untuk menyajikan data dan informasi tentang pemanasan global dan memberikan usulan penanggulangan masalah. Pengetahuan dan keterampilan akan diperoleh dengan perilaku ilmiah (diantaranya rasa ingin tahu, kreatif, inovatif dan peduli lingkungan) yang dilakukan siswa. Jadi materi pemanasan global sesuai diterapkan dengan model pembelajaran problem solving karena menekankan pada pemecahan masalah.

Kegiatan dalam pembelajaran problem solving menggunakan unsur-unsur kreativitas, yaitu memungkinkan siswa untuk berimajinasi, menggunakan ide-ide, dan berpikir tentang berbagai macam kemungkinan pemecahan masalah. Masalah dapat dipecahkan melalui perilaku ilmiah dan keterampilan berpikir kreatif yang dimiliki. Cara yang dapat dilakukan adalah mengajarkan siswa memecahkan masalah pemanasan global melalui perilaku ilmiah sehingga dapat membangun ide-ide kreatif dalam menanggulangi pemanasan global dengan model pembelajaran problem solving. Siswa kemudian dapat menyajikan data dan informasi tentang pemanasan global sesuai kreativitas mereka sendiri.

Berdasarkan pengalaman mengajar peneliti, sebagian besar pembelajaran di kelas hanya bersifat satu arah dan hanya bersifat tekstual dan konseptual yang meliputi: definisi istilah-istilah, penyebab dan solusi penanggulangan masalah. Hal ini menyebabkan pengetahuan siswa cenderung kurang berkembang dan solusi permasalahan yang disajikan pun cenderung sama dari waktu ke waktu (kurang bervariasi) dan bersifat tekstual konseptual saja. Sebagian besar siswa belum menyadari bahwa apa yang mereka lakukan sehari-hari dapat memberi andil semakin buruknya masalah pemanasan global. Masalah pemanasan global ini selalu berkembang dari waktu ke waktu dan membutuhkan penanganan yang nyata dan segera dari semua lapisan masyarakat, termasuk para siswa selaku generasi muda penerus bangsa.

Data observasi awal dilakukan di SMPN 1 Kediri menunjukkan bahwa pembelajaran IPA kelas VII khususnya materi pemanasan global selama ini belum membuat siswa kreatif. SMPN 1 Kediri merupakan salah satu sekolah unggulan dan mempunyai kualifikasi input siswa tinggi. Hasil tes keterampilan berpikir kreatif materi pemanasan global yang mengacu pada indikator kreatif menunjukkan bahwa $62,5 \%$ siswa kurang kreatif, $21,8 \%$ cukup kreatif, $12,5 \%$ kreatif dan $3,1 \%$ sangat kreatif. Berdasar angket siswa diketahui bahwa 96,8\% siswa sebenarnya paham bahwa pemanasan global bisa dipecahkan dari berbagai bidang, tetapi jawaban siswa pada tes keterampilan berpikir kreatif menunjukkan bahwa solusi penanggulangan pemanasan global cenderung sama (tekstual), belum memberikan solusi beragam dan tidak memiliki ide baru yang tidak biasa. Berdasarkan wawancara guru diketahui bahwa materi pemanasan global selama ini dilakukan dengan menggunakan direct instruction dan analisis data dari artikel yang diperoleh dari koran atau internet. Hal ini menyebabkan siswa kurang kreatif karena kemampuan berpikir siswa kurang dikembangkan.

Pembelajaran akan berhasil bila ada perangkat pembelajaran yang baik pula. Perangkat pembelajaran dapat diartikan sebagai alat, perlengkapan yang direncanakan atau disiapkan untuk melaksanakan proses pembelajaran. Perangkat pembelajaran yang dimaksudkan dalam hal ini meliputi silabus, rencana pelaksanaan pembelajaran (RPP), buku ajar siswa 
(BAS), lembar kegiatan siswa (LKS), dan instrumen penilaian hasil belajar.

Berdasarkan pengalaman mengajar dan observasi peneliti, sebelum adanya Kurikulum 2013 guru jarang sekali yang membuat/mengembangkan perangkat pembelajaran dengan rinci dan penuh pemikiran. Perangkat pembelajaran hanya disiapkan seadanya dan terkesan hanya sekedar syarat administrasi yang harus dipenuhi ketika ada pengawas. Namun dengan adanya Kurikulum 2013 saat ini, pemerintah telah menyediakan perangkat pembelajaran standar yang digunakan sebagai acuan pendidikan di seluruh Indonesia.

Perangkat pembelajaran IPA SMP kelas VII yang dikembangkan pemerintah sudah menggunakan pendekatan dan langkah pembelajaran saintifik. Kegiatan pembelajaran sepenuhnya diarahkan pada pengembangan ranah sikap, pengetahuan, dan keterampilan. Namun, perangkat pembelajaran IPA SMP kelas VII yang dikembangkan pemerintah pada Kurikulum 2013 masih mempunyai kelemahan. Materi yang disajikan cenderung bersifat dasar dan ringkas. Kegiatan siswa dituliskan pada buku siswa secara jelas dan menggiring siswa untuk mengikuti langkahlangkah pemecahan masalah. Hal ini dapat menghambat kreativitas siswa. Beberapa materi pembelajaran dalam buku ajar belum sesuai dengan kompetensi dasar yang diharapkan. Contohnya pada materi pemanasan global, tugas kliping yang diberikan pada siswa belum dapat memenuhi kompetensi keterampilan dalam memberikan usulan/ide penanggulangan pemanasan global. Keterampilan berpikir kreatif diperlukan untuk memberikan usulan/ide.

Berdasarkan uraian di atas, penulis berupaya mengembangkan perangkat pembelajaran dengan model problem solving sebagai salah satu alternatif untuk melatihkan keterampilan berpikir kreatif siswa SMP pada materi pemanasan global.

\section{METODE PENELITIAN}

Jenis penelitian ini adalah penelitian pengembangan Perangkat pembelajaran yang dikembangkan meliputi silabus, RPP, BAS, LKS dan lembar penilaian. Penelitian ini bertujuan untuk mendeskipsikan keefektifan perangkat pembelajaran yaitu keterampilan berpikir kreatif siswa.

Pengembangan perangkat pada penelitian ini menggunakan model pengembangan perangkat 3D yang terdiri dari 3 tahap pengembangan yaitu pendefinisian (define), perancangan (design), dan pengembangan (develop). Desain ujicoba penelitian menggunakan rancangan one-group pretest-posttest design. Subjek penelitian ini adalah perangkat pembelajaran IPA dengan model problem solving pada materi pemanasan global. Perangkat ini diterapkan pada 32 siswa kelas VII, tahun pelajaran 2015/2016, bulan Oktober 2015, SMP Negeri 1 Kediri.

Pengumpulan data dilakukan dengan menggunakan teknik tes dan dokumentasi. Instrumen penilaian menggunakan keterampilan berpikir kreatif siswa. Keefektifan perangkat diperoleh dengan cara menganalisis skor tes kreativitas siswa sebelum dan sesudah pembelajaran dengan problem solving. Tingkat/kriteria kreativitas siswa dianalisis baik secara umum (mencakup 4 indikator kreatif fluency, flexibility, originality, dan elaboration) maupun dianalisis tiap indikator kreatif yang dilatihkan. Penilaian keterampilan berpikir kreatif dihitung dengan rumus:

$$
\text { Persentase Skor }=\frac{\text { jumlah } \text { skor }}{\text { skor maksimal }} \times 100 \%
$$

(Diadaptasi dari Utami, 2014)

Kriteria kreativitas dari hasil persentase skor disajikan pada Tabel 1 berikut.

Tabel 1. Kriteria Kreativitas Siswa

\begin{tabular}{|c|c|}
\hline Interval Skor Rata-Rata & Kategori \\
\hline $81,6 \%-100 \%$ & Sangat Kreatif \\
\hline $61,2 \%-81,5 \%$ & Kreatif \\
\hline $40,8 \%-61,1 \%$ & Cukup Kreatif \\
\hline $20,4 \%-40,7 \%$ & Kurang Kreatif \\
\hline $0,00 \%-20,3 \%$ & Tidak Kreatif \\
\hline
\end{tabular}

Sumber: Diadaptasi dari Khanafiyah (2010).

Efektivitas pembelajaran problem solving untuk melatihkan keterampilan berpikir kreatif diuji menggunakan rumus $N$-gain sebagai berikut.

$$
\begin{array}{cl}
\text { Keterangan: } & \langle g\rangle=\frac{S_{\text {post }}-S_{\text {pre }}}{S_{\text {max }}-S_{\text {pre }}} \\
<\mathrm{g}> & : \text { Peningkatan keterampilan berpikir } \\
& \text { kreatif siswa } \\
\text { Spost } & : \text { Nilai posttest } \\
\text { Spre } & : \text { Nilai pretest } \\
\text { Smax } & : \text { Nilai maksimal }
\end{array}
$$

Hasil perhitungan $N$-gain kemudian dikonversikan sesuai Tabel 2 berikut:

Tabel 2. Kriteria Normalized-gain (N-gain)

\begin{tabular}{|l|l|}
\hline Skor $\boldsymbol{N}$-gain & Kriteria Normalized Gain \\
\hline $0,70<N$-gain & Tinggi \\
\hline $0,30 \leq N$-gain $\leq 0,70$ & Sedang \\
\hline$N$-gain $<0,30$ & Rendah \\
\hline
\end{tabular}

Sumber: Hake (1999)

\section{HASIL PENELITIAN DAN DISKUSI}

Perangkat pembelajaran dikategorikan efektif apabila terjadi peningkatan keterampilan berpikir kreatif siswa dengan hasil $N$-gain $\geq 0,30$. Penilaian 
keterampilan berpikir kreatif diperoleh dari tes kreativitas berbentuk pertanyaan uraian (open-ended questions and varied solutions solving) materi pemanasan global. Tes ini diadaptasi dari Munandar (2012). Masing-masing item tes dinilai dengan metode penskoran berdasarkan indikator fluency, flexibility, originality dan elaboration yang telah dikembangkan peneliti. Tes ini diberikan ke siswa sebelum dan setelah pembelajaran dilakukan untuk mengetahui peningkatan keterampilan berpikir kreatif yang dimiliki siswa. Tingkat/kriteria kreativitas diperoleh dengan cara menganalisis skor tes kreativitas siswa sebelum dan sesudah pembelajaran dengan model problem solving baik secara umum (4 indikator kreatif) maupun tiap indikator kreatif.

\section{A. Keterampilan Berpikir Kreatif Secara Umum}

Kriteria kreativitas secara umum menunjukkan bahwa seluruh siswa termasuk dalam kategori cukup kreatif (100\%) sebelum pembelajaran dilakukan. Penerapan model pembelajaran problem solving menggunakan perangkat yang peneliti kembangkan menghasilkan pencapaian $\mathrm{N}$-gain kategori sedang dan tinggi dengan rincian 26 siswa kreatif $(81,25 \%)$ dan 6 siswa sangat kreatif (18,75\%). Penelitian ini, peningkatan keterampilan berpikir kreatif siswa juga didukung oleh peningkatan hasil belajar siswa baik dari aspek sikap, pengetahuan, dan keterampilan. Keterampilan berpikir kreatif mengukur ciri kognitif yang mencerminkan kelancaran, keluwesan, orisinalitas, dan elaborasi dalam berpikir. Taksonomi Bloom yang telah direvisi menempatkan berpikir kreatif terdapat pada level C6 (create) yang merupakan level kognitif tingkat tinggi. Siswa yang sudah menguasai level kognitif tingkat tinggi secara umum berarti telah mampu menguasai level kognitif di bawahnya (level kognitif tingkat rendah dan menengah) sehingga hasil belajar siswa secara umum juga akan meningkat. Woolfolk (2009) menyatakan bahwa dasar kreativitas diantaranya adalah pengetahuan yang banyak tentang suatu hal. Gardner dalam Beetlestone (2013) yang memandang kreativitas sebagai salah satu dari multiple intelegency yang melibatkan berbagai macam fungsi otak. Aspek kreatif otak dapat membantu menjelaskan dan menginterpretasikan konsep-konsep yang abstrak, sehingga memungkinan pencapaian penguasaan yang lebih luas.

Keterampilan berpikir kreatif sebanding dengan hasil belajar (Munandar, 2012). Kreativitas menentukan tinggi rendahnya hasil belajar yang dicapai siswa, artinya siswa yang memiliki kemampuan berpikir yang kreatif tinggi akan memperoleh kemudahan dalam belajar daripada siswa yang memiliki kemampuan berpikir kreatif rendah. Hal ini sejalan dengan penelitian yang dilakukan oleh Miftah (2012) yang menyatakan bahwa terdapat hubungan positif antara kreativitas dengan hasil belajar IPA pada siswa kelas V Sekolah Dasar. Syam dkk (2011) juga menyatakan terdapat hubungan kreativitas dengan hasil belajar fisika yang diterapkan pada siswa kelas VIII SMP.

\section{B. Keterampilan Berpikir Kreatif Tiap Indikator}

Tingkat kreativitas siswa juga dianalisis secara rinci pada setiap indikator untuk mengetahui indikator berpikir kreatif mana yang berperan meningkatkan keterampilan berpikir kreatif siswa. Rincian analisis keterampilan berpikir kreatif siswa pada setiap indikator tersaji pada Tabel 3 sebagai berikut.

Tabel 3. Analisis Keterampilan Berpikir Kreatif Siswa Pada Tiap Indikator

\begin{tabular}{|l|c|c|l|l|}
\hline $\begin{array}{l}\text { Indik } \\
\text { ator }\end{array}$ & $\begin{array}{l}\text { Total Skor } \\
\text { Pretest pada } \\
\text { idikator }(\%)\end{array}$ & $\begin{array}{l}\text { Total Skor } \\
\text { Postest pada } \\
\text { idikator }(\%)\end{array}$ & $\begin{array}{l}\text { N- } \\
\text { Gain }\end{array}$ & $\begin{array}{l}\text { Katego } \\
\text { ri }\end{array}$ \\
\hline 1 & 51,04 & 79,17 & 0,57 & Sedang \\
\hline 2 & 40,63 & 79,27 & 0,65 & Sedang \\
\hline 3 & 32,29 & 57,73 & 0,38 & Sedang \\
\hline 4 & 67,19 & 93,85 & 0,81 & Tinggi \\
\hline
\end{tabular}

Indikator 1: Memberikan sejumlah jawaban yang logis dan sesuai dengan pertanyaan yang diberikan (Fluency). Indikator 2: Mencari banyak alternatif atau arah yang berbeda-beda (Flexibility). Indikator 3: Memikirkan cara yang tidak lazim untuk mengungkapkan diri (Originality) Indikator 4: Mampu memperkaya dan mengembangkan suatu gagasan atau produk (Elaboration).

Berdasarkan Tabel 3 diketahui bahwa indikator elaboration lebih berperan meningkatkan keterampilan berpikir kreatif siswa pada penelitian ini. Bimbingan lebih lanjut dan terus-menerus diperlukan untuk melatihkan /meningkatkan keterampilan berpikir kreatif siswa terutama pada indikator fluency, flexibility dan originality. Analisis keterampilan berpikir kreatif siswa tiap indikator yang diperoleh adalah sebagai berikut.

Keterampilan berpikir kreatif siswa dalam memperkaya/mengembangkan suatu ide/gagasan (elaboration) pada penelitian ini mencapai kriteria $\mathrm{N}$ gain tinggi. Elaboration pada penelitian ini diketahui berdasar jumlah rincian atau pengembangan gagasan yang diberikan siswa. Tes keterampilan berpikir kreatif indikator elaboration pada akhir pembelajaran (posttest) menunjukkan bahwa 78,1\% siswa berhasil memberikan $>4$ rincian atau pengembangan gagasan dengan logis (sangat kreatif), sedangkan $21,8 \%$ siswa memberikan 3-4 rincian atau pengembangan gagasan dengan logis sesuai pertanyaan yang diberikan (kreatif).

Pencapaian $N$-gain tinggi pada indikator elaboration ini didukung oleh latar belakang siswa yang memiliki wawasan yang cukup sehingga lebih mudah memerinci objek/materi dengan kata-kata 
sendiri dan mengembangkan/menerapkan ide dalam kehidupan sehari-hari. Aktivitas siswa selama pembelajaran juga berperan dalam meningkatkan kemampuan elaboration siswa. Siswa terbiasa untuk menuliskan dengan rinci langkah kerja percobaan yang dilakukan, memperkaya/ mengembangkan gagasan berdasar gagasan yang sudah ada, membuat simpulan dengan memperhatikan rincian data hasil percobaan, memperhatikan detil-detil langkah percobaan yang dimiliki, dan memerinci penerapan ide-ide kreatif yang dimiliki dalam kehidupan sehari-hari.

Peningkatan indikator elaboration dipengaruhi oleh langkah-langkah pembelajaran model problem solving (Tennyson \& Breuer, 2002). Penyajian berbagai masalah menjadikan siswa memperhatikan masalah secara detail, aktif mencari dan memberikan solusi/jawaban secara rinci dan mampu mengembangkan ide/jawaban dengan mengelaborasi pengetahuan yang sudah dimiliki dengan informasi baru yang diperoleh. Keterampilan berpikir rinci (elaboration) pada penelitian ini mempunyai kriteria $\mathrm{N}$ gain paling tinggi dibandingkan indikator kreatif lainnya. Hal ini sejalan dengan penelitian Fard et al., (2014) yang menunjukkan bahwa elaboration merupakan indikator kreatif yang paling berperan dalam meningkatkan kreativitas siswa dengan penerapan pembelajaran problem solving.

Indikator flexibility dan fluency memiliki pencapaian $\mathrm{N}$-gain sedang. Terjadinya peningkatan pencapaian indikator flexibility dan fluency dapat terjadi karena siswa terbiasa memecahkan masalah dengan cara mencari di berbagai sumber informasi, berdiskusi, dan bertukar pikiran sehingga menambah wawasan siswa. Munandar (2012) menyatakan bahwa siswa yang mempunyai kemampuan berpikir lancar (fluency) berperilaku sering mengajukan banyak pertanyaan atau menjawab suatu pertanyaan dengan sejumlah jawaban. Pencapaian $N$-gain flexibility dan fluency pada penelitian ini menunjukkan nilai yang tidak berbeda siginifikan. Hal ini menunjukkan bahwa flexibility dan fluency sangat terkait satu sama lain, siswa yang menghasilkan lebih banyak solusi memiliki kesempatan untuk menghasilkan solusi dari berbagai sudut pandang yang berbeda.

Hal ini tampak dari jumlah jawaban posttest siswa pada penelitian ini. Siswa sebanyak $76,6 \%$ pada penelitian ini menghasilkan 2-3 jawaban logis sesuai pertanyaan yang diberikan (kreatif), sedangkan 23,4\% siswa menghasilkan $>3$ jawaban logis sesuai pertanyaan yang diberikan (sangat kreatif). Siswa sebanyak 53,1\% memberikan 2-3 alternatif atau arah yang berbeda sesuai pertanyaan yang diberikan (kreatif), 34,3\% siswa memberikan $>3$ alternatif atau arah yang berbeda sesuai pertanyaan yang diberikan (sangat kreatif), dan 15,6\% siswa hanya memberikan satu alternatif atau arah yang berbeda sesuai pertanyaan yang diberikan (kurang kreatif).

Pencapaian indikator flexibility dan fluency pada penelitian ini juga didukung oleh aktivitas siswa yang dilakukan selama pembelajaran dengan model problem solving. Siswa terlibat secara aktif dalam mengidentifikasi masalah, menentukan tujuan percobaan, dan mencari alternatif jawaban/ide. Hal ini didukung penelitian Putra, dkk (2012) yang menunjukkan bahwa pembelajaran yang berbasis masalah dapat meningkatkan indikator kreatif flexibility dan fluency.

Pencapaian $\mathrm{N}$-gain pada indikator fluency memiliki kriteria sedang karena siswa belum maksimal dalam menghasilkan banyak jawaban tentang dampak lebih lanjut melelehnya es di kutub terhadap lingkungan dan makhluk hidup. Hal ini disebabkan siswa cenderung terbiasa menjawab soal sesuai minimal jumlah yang diminta, belum berani/belum terbiasa menuliskan banyak jawaban/melebihi dari yang diminta. Siswa lebih suka mengerjakan soal secara tepat sehingga jawaban yang diberikan siswa belum bervariasi/belum melihat dari berbagai sudut pandang menghasilkan pencapaian $\mathrm{N}$-gain sedang (belum maksimal) pada indikator flexibility. Bimbingan lebih lanjut diperlukan untuk meningkatkan kemampuan berpikir lancar (fluency) dan kemampuan berpikir luwes (flexibility) siswa.

Berpikir orisinal siswa pada penelitian ini diketahui dari orisinalitas/keunikan gagasan/ide yang diberikan dalam memberikan solusi pemanasan global. Siswa sebanyak $40,6 \%$ memberikan $<3$ ide yang tidak biasa, unik, dan cerdas atau $0-5 \%$ memberikan ide serupa (kreatif), hanya 9,3\% siswa yang memberikan $>3$ ide yang tidak biasa, unik, dan cerdas atau $0-5 \%$ memberikan ide serupa (sangat kreatif), sisanya 50\% siswa memberikan ide yang sudah umum atau $>5 \%$ sampel memberikan ide serupa (kurang kreatif).

Berpikir orisinal siswa juga dilihat dari tabel yang dibuat dalam menyajikan data/informasi pemanasan global (pada posttest). Siswa sebanyak $68,7 \%$ membuat tabel yang sudah umum $(>5 \%$ sampel membuat tabel serupa) dan mengandung unsur keindahan (terdapat goresan, warna) yang mendukung (kreatif). Siswa yang sangat kreatif hanya 3,1\% yaitu dapat membuat tabel dengan cara yang unik, tidak biasa, cerdas $(<5 \%$ sampel membuat tabel serupa) dan mengandung unsur keindahan (terdapat goresan, warna) yang mendukung, sisanya sebesar $28,1 \%$ siswa membuat tabel yang sudah umum ( $>5 \%$ sampel membuat tabel serupa) dan tidak mengandung unsur keindahan (tidak terdapat goresan, warna) yang mendukung (kurang kreatif). Tabel yang dibuat siswa semuanya sesuai konsep materi.

Indikator originality siswa mengalami peningkatan dengan pencapaian $N$-gain sedang. Pencapaian 
indikator originality siswa pada penelitian ini didukung oleh aktivitas siswa yang dilakukan selama pembelajaran dengan bantuan lembar kegiatan siswa. Siswa secara aktif mengeksplorasi dan menggambar ide-ide rancangan percobaan didasarkan tujuan percobaan yang akan dilakukan dan alat bahan yang tersedia. Siswa kemudian menentukan satu ide rancangan yang akan dilakukan. Data hasil percobaan dituliskan siswa dalam bentuk tabel sesuai kreasi siswa masing-masing. Hal ini didukung penelitian Alexander (2007) yang menunjukkan peningkatan indikator originality dengan penerapan pembelajaran creative problem solving.

Berpikir orisinal lebih menfokuskan pada proses individu untuk memunculkan ide baru yang merupakan gabungan ide-ide sebelumnya yang belum diwujudkan atau masih dalam pemikiran. Berpikir kreatif ditandai dengan adanya ide baru yang dimunculkan sebagai hasil dari proses berpikir tersebut. Munandar (2012) menyatakan bahwa berpikir orisinal (originality) berkaitan dengan hasil belajar. Hal ini sejalan dengan hasil belajar yang diperoleh pada penelitian ini. Hasil belajar aspek sikap, pengetahuan dan keterampilan (terlampir) pada penelitian ini mencapai ketuntasan $100 \%$.

Indikator originality memiliki nilai $\mathrm{N}$-gain paling rendah diantara indikator berpikir kreatif lainnya pada penelitian ini karena siswa belum berani mengeluarkan ide-ide unik/berpikir "out of the box" dalam membuat tabel dan memberikan usulan penanggulangan pemanasan global. Siswa masih terpaku pada pembuatan tabel dan solusi yang sudah ada dan umum dipelajari sehingga bimbingan dan latihan harus terus dilakukan secara intensif.

Hasil pencapaian $\mathrm{N}$-gain keterampilan berpikir kreatif tiap indikator juga dipengaruhi oleh usia siswa. Penelitian ini diterapkan pada siswa SMP kelas VII yang berusia sekitar 13 tahun sehingga pencapaian tingkat berpikir kreatifnya belum optimal. Hal ini sesuai dengan Lehman dalam Filsaime (2008) yang menyatakan bahwa puncak kreatif seseorang terjadi pada usia 30-an, namun demikian melatihkannya dapat dimulai sejak anak-anak (Munandar, 2012). Oleh karena itu peneliti melatihkan keterampilan berpikir kreatif pada anak SMP pada penelitian ini.

Berdasarkan hasil diskusi keterampilan berpikir kreatif tiap indikator dapat disimpulkan bahwa pada penelitian ini, kemampuan berpikir rinci (elaboration) paling berperan dalam meningkatkan keterampilan berpikir kreatif siswa pada materi pemanasan global dengan penerapan model pembelajaran problem solving. Bimbingan lebih lanjut dan terus-menerus diperlukan untuk melatihkan/meningkatkan keterampilan berpikir kreatif siswa terutama pada indikator flexibility, fluency dan originality.

\section{Generalisasi Keterampilan Berpikir Kreatif}

Hasil penilaian keterampilan berpikir kreatif siswa baik secara umum maupun pada tiap indikator menunjukkan bahwa pembelajaran problem solving menggunakan perangkat yang peneliti kembangkan dapat meningkatkan keterampilan berpikir kreatif siswa pada materi pemanasan global. Hasil penelitian ini didukung oleh Fard et al., (2014) yang menyatakan bahwa metode pembelajaran problem solving dapat meningkatkan rata-rata skor kreativitas, baik dari segi fluency, flexibility, originality, dan elaboration. Pembelajaran creative problem solving dapat meningkatkan kreativitas siswa kelas 9 pada program pengenalan ilmu dan teknologi agrikultur (Alexander, 2007).

Keterampilan berpikir kreatif siswa dapat meningkat dengan pembelajaran model problem solving karena kegiatan problem solving menggunakan unsurunsur kreativitas yang memungkinkan siswa aktif berimajinasi, menggunakan ide-ide, dan berpikir tentang berbagai macam kemungkinan (Beetlestone, 2013). Perangkat dan proses pelaksanaan pembelajaran juga berperan dalam melatihkan keterampilan berpikir kreatif.

Perangkat yang peneliti kembangkan menggunakan masalah/ilustrasi masalah sebagai dasar pembelajaran untuk siswa pecahkan. Dalam proses pemecahan masalah, siswa dilatih untuk terampil berpikir kreatif melalui pertanyaan-pertanyaan yang diberikan. Pada penelitian ini, LKS merupakan salah satu alat latihan bagi siswa untuk berpikir kreatif. Berdasarkan masalah yang disajikan, siswa diminta berlatih (1) memberikan sejumlah jawaban yang logis dan sesuai pertanyaan (fluency) melalui kegiatan identifikasi masalah dan peluang dan mendefinisikan tujuan, (2) mencari banyak alternatif atau arah yang berbeda-beda (flexibility) dan memikirkan cara yang tidak lazim untuk mengungkapkan diri (originality) melalui kegiatan eksplorasi yang mungkin, (3) memikirkan cara yang tidak lazim untuk mengungkapkan diri (originality) dan elaboration melalui kegiatan antisipasi hasil dan tindakan, dan (4) mampu memperkaya dan mengembangkan suatu gagasan atau produk (elaboration) melalui kegiatan lihat kembali dan pelajari.

Guru membutuhkan ekstra usaha/bimbingan untuk melatihkan keterampilan berpikir kreatif pada siswa terutama di awal pembelajaran. Hal ini disebabkan siswa belum terbiasa mengungkapkan pendapat, pasif, cenderung malu-malu dan tidak berani berpikir di luar konteks. Oleh karena itu, guru menyajikan masalah nyata yang berhubungan dengan kehidupan sehari-hari agar siswa lebih termotivasi, lebih mudah memahami, dan berimajinasi. Hal ini sejalan dengan Munandar (2012) yang menjelaskan bahwa perkembangan optimal 
dari kemampuan berpikir kreatif berhubungan erat dengan proses pembelajaran. Berpikir kreatif akan muncul dalam suasana pembelajaran yang menyenangkan, memotivasi siswa untuk berpartisipasi aktif, memberikan ruang kepada siswa untuk berpikir dan berani mengemukakan pendapat, atau ketika siswa diberi kesempatan untuk bekerja sesuai dengan minatnya.

Bimbingan guru dengan memberikan pertanyaan terbuka pada siswa juga merangsang siswa untuk berpikir kreatif. Hal ini sesuai dengan McGregor (2007) yang menyatakan bahwa melakukan problem solving, memberi open-ended questions dan varied solutions solving merupakan strategi atau taktik yang dapat diterapkan dalam pembelajaran untuk melatihkan keterampilan berpikir kreatif. Hal ini didukung oleh Kurniawati dkk. (2012) yang menyatakan bahwa pembelajaran dengan menggunakan pendekatan openended berbasis problem solving pada mata pelajaran matematika menjadikan siswa aktif, dan menjadikan proses pembelajaran menjadi lebih menyenangkan, meningkatkan minat siswa, dan lebih paham terhadap materi. Malik et al. (2010) menyatakan pembelajaran problem solving dapat meningkatkan sikap positif siswa dalam pembelajaran sains. Sikap positif siswa terkait erat dengan hasil belajar siswa sains, termasuk kreativitas.

Penerapan berpikir kreatif dalam pemecahan masalah akan menghasilkan banyak ide yang berguna dalam menemukan penyelesaian masalah (problem solving). Siswa diarahkan untuk melakukan penyelidikan autentik untuk mencari penyelesaian terhadap masalah yang diberikan dengan cara mengidentifikasi masalah dan peluang, mendefinisikan tujuan, mengeksplorasi strategi yang mungkin, mengantisipasi hasil dan tindakan, dan melihat kembali dan pelajari (Bransford dan Stein dalam Slavin, 2011). Hal ini didukung oleh Dogru (2008) yang menyatakan bahwa pembelajaran problem solving pada mata pelajaran sains dapat meningkatkan keterampilan kegiatan ilmiah, meningkatkan poin sikap problem solving dan meningkatkan nilai yang diperoleh dalam tes materi lingkungan). Penelitian yang dilakukan oleh Ifamuyiwa \& Ajilogba (2012) menunjukkan bahwa pembelajaran problem solving dapat meningkatkan prestasi belajar dan retensi siswa.

\section{KESIMPULAN}

\section{A. Simpulan}

Berdasarkan diskusi hasil penelitian yang diuraikan, dapat disimpulkan bahwa pengembangan perangkat pembelajaran dengan model problem solving dinyatakan efektif untuk melatihkan keterampilan berpikir kreatif siswa SMP pada materi pemanasan global.
B. Saran

1. Pengelolaan waktu yang efektif dan efisien diperlukan dalam menerapkan pembelajaran dengan model problem solving, sehingga pembelajaran berjalan berlangsung lebih optimal.

2. Langkah-langkah pembelajaran model problem solving perlu dikembangkan menggunakan pengembangan indikator berpikir kreatif lainnya, sehingga siswa dapat meningkatkan keterampilan berpikir kreatifnya.

\section{REFERENSI}

Alexander, K.D. (2007). Effects of Instruction in Creative Problem Solving On Cognition, Creativity, And Satisfaction among Ninth Grade Students in an Introduction to World Agricultural Science and Technology Course (Unpublished Dissertation). Texas Tech University.

Arends, Richard L. (2012). Learning to Teach. New York: The McGraw-Hill Companies, Inc.

Beetlestone, Florence. (2013). Creative Learning Strategi Pembelajaran untuk Melesatkan Kreatifitas Siswa. Bandung: Nusa Media.

Devi, P.K., Sofiraeni, R., Khairuddin. (2009). Pengembangan Perangkat Pembelajaran. Bandung: PPPPTK IPA.

Dogru, M. (2008). The Application of Problem Solving Method on Science Teacher Trainees on The Solution of The Environmental Problems. Journal of Environmental \& Science Education, 2008, 3 (1), 9-18.

Fard, A.E., Bahador, A., Moghadam, M.N., Rajabi, H., Moradi, A.N. (2014). The Possible Impact of Problem-solving Method of Instruction on Exceptional Students' Creativity. Journal of Education and Training Studies Vol. 2, No. 3; July 2014. USA: Redfame Publishing.

Filsaime, Dennis K. (2008). Menguak Rahasia Berpikir Kritis dan Kreatif. Jakarta: Prestasi Pustaka.

Florida, R., Mellander, C., Stolarick, K., Silk, K., Matheson, Z., Hopgood, M. (2011). Creativity and Prosperity: The Global Creativity Index. Toronto: Martin Prosperity Institute.

Hake, R.R. (1999). Analyzing Change/Gain Scores. USA: AERA-D - American Educational Research Association's Division D, Measurement and Research Methodology.

Ifamuyiwa, A.S \& Ajilogba, S.I. (2012). A Problem Solving Model as a Strategy For Improving Secondary School Students' Achievment and Retention in Further Mathematics. ARPN Journal of Science and Tecnology Vol. 2, No. 2, March 2012.

Khanafiyah, S., Rusilowati, A. (2010). Penerapan Pendekatan Modified Free Inquiry sebagai

Keefektifan pengembangan perangkat pembelajaran model 1075 problem solving untuk ... 
Upaya Meningkatkan Kreativitas Mahasiswa Calon Guru dalam Mengembangkan Jenis Eksperimen dan Pemahaman Terhadap Materi Fisika. Jurnal Berkala Fisika, Vol 13. No. 2, pp E7-E17. Universitas Negeri Semarang.

Kurniawati, Ira and Kuswadi, Yemi and Chrisnawati, Ekana, H. (2012). Pengembangan Model dan Perangkat Pembelajaran Open Ended Berbasis Problem Solving sebagai Strategi untuk Meningkatkan Kemampuan Berpikir Matematika Siswa di RSMABI Sukoharjo. Artikel Semnas Matematika \& Pendidikan Matematika UNS 2012. Solo: UNS.

Malik, M.A., Shah, Z.A., Iqbal, Z., Rauf, M. (2010). Effect of Problem Solving Teaching Strategy on 8th Grade Students' Attitude Towards Science. Journal of Education and Practice, ISSN 2222-1735 (Paper), ISSN 2222-288X (Online), Vol. 1, No. 3, 2010. www.iiste.org.

McGregor. (2007). Developing Thinking Developing Learning a Guide to Thinking Skills in Education. England Open University Press Mcgraw-Hill Education.

Miftah, Y. (2012). Pengaruh Kreativitas Siswa terhadap Hasil Belajar Siswa Kelas V pada Mata Pelajaran Ilmu Pengetahuan Alam Sekolah Dasar Negeri Gugus Handayani Kecamatan Kertek di Wonosobo Tahun Pelajaran 2011/2012 (Skripsi tidak Dipublikasikan). Salatiga: Program Studi S1 Pendidikan Guru Sekolah Dasar Fakultas Keguruan Dan Ilmu Pendidikan Universitas Kristen Satya Wacana.

Monahan, T. (2002). The Do-It-Yourself Lobotomy: Open Your Mind to Greater Creative Thinking. New York: John Wiley \& Sons.

Munandar, Utami. (2012). Pengembangan Kreativitas Anak Berbakat. Jakarta: Rineka Cipta.

Myrmel, Mary Kay. (2003). Effects of Using Creative Problem Solving in Eighth Grade Technology Education Class at Hopkins North Junior High School (Unpublished Thesis). Stout: University of Wisconsin.

Odja, A.H., Jatmiko, B., Supardi, Z.A. (2014). Model Konseptual Observasi Ilmiah Berorientasi Kemandirian dalam Pembelajaran Sains untuk Melatihkan Keterampilan Pemecahan Masalah. Prosiding Seminar Nasional Pendidikan Sains Tahun 2014 "Inovasi Pendidikan Sains dalam Menyongsong Pelaksanaan Kurikulum 2013". Surabaya: Jaudar Press.
Permendikbud No. 54 Tahun 2013 tentang Standar Kompetensi Lulusan Pendidikan Dasar dan Menenegah. Jakarta: Depdikbud.

Permendikbud No. 58 Tahun 2104 tentang Kurikulum 2013 Sekolah Menengah Pertama/Madrasah Tsanawiyah. Jakarta: Depdikbud.

Piirto, Jane. (2011). Creativity for 21st Century Skills: How to Embed Creativity into The Curriculum. Rotterdam: Sense Publishers.

Putra, T.T., Irwan, Vionanda, D. (2012). Meningkatkan Kemampuan Berpikir Kreatif Siswa dengan Pembelajaran Berbasis Masalah. Jurnal Pendidikan Matematika Part 3 Vol. 1 No. 1.

Riduwan. (2010). Skala Pengukuran Variabel-Variabel Penelitian. Bandung: Alfabeta.

Samatowa, U. (2006). Bagaimana Membelajarkan IPA di Sekolah Dasar. Jakarta: Direktorat Pendidikan Nasional.

Slavin, R.E. (2011). Psikologi Pendidikan Teori dan Praktik. Edisi Kesembilan. Jakarta: PT. Indeks.

Syam, I., Subaer, Aslim. (2011). Hubungan Antara Kreativitas Belajar dengan Hasil Belajar Fisika Siswa Kelas VIII SMP Negeri 1 Sinjai Utara. JSPF Vol 31, Mei 2011. Makasar: Jurusan Fisika Universitas Negeri Makasar.

Tennyson, R.D., \& Breuer, K. (2002). Improving Problem Solving and Creativity through Use of Complex-Dynamic Simulations. Computers in Human Behaviour, 18, 650-668.

Trilling \& Fadel. (2009). 21st Century Skills Learning For Life In Our Times. San Francisco: John Wiley \& Sons, Inc.

Utami, A. U. (2014). Pengembangan Perangkat Pembelajaran IPA Model Inkuiri dengan Tugas Proyek untuk Melatihkan Kemampuan Berpikir Kreatif (Tesis tidak dipublikasikan). Surabaya: Program Pendidikan Sains Program Pasca Sarjana Universitas Negeri Surabaya.

VanGundy, A.B. (2005). 101 Activities for Teaching Creativity and Problem Solving. USA: John Wiley \& Sons, Inc.

Wenno, I.H. (2010). Pengembangan Model Modul IPA Berbasis Problem Solving Method Berdasarkan Karakteristik Siswa dalam Pembelajaran di SMP/MTs. Ambon: FKIP Universitas Pattimura Ambon.

Woolfolk, A. (2009). Educational Physchology Active Learning Edition. Edisi Bahasa Indonesia. Yogyakarta: Pustaka Pelajar. 